\title{
DEVELOPMENT OF AN SMALL EXPRESSION MACHINE TO PURPOSE PRODUCTION OF FISH FEED PELLETS
}

\section{Dr. Hamada El-Khateeb ${ }^{1}$ Dr.A.M.Drees ${ }^{2} \quad$ Dr. S.K.Abd El-Aty ${ }^{3}$ \\ ABSTRACT}

Field experiment were carried during 2007 at the Sakha Aquaculture Research Station, Kafr El-Sheikh, Governorate, to evaluate the feasibility of using a small expression machine for oil extraction to suit production of fish feed pellets. The effect of some parameters such as, screw speeds $(1.50,1.90$, and $2.25 \mathrm{~m} / \mathrm{s})$, moisture content of ration $(12.8,16.5$, and $22.0 \%)$, screw pitch (50.0 and $80.0 \mathrm{~mm}$ ) and two different die shape (Perforated Cylinder - Internal Cone) on energy requirements, machine productivity, pellets bulk density, pellets durability, floating time and pelleting efficiency.

The obtained results showed that increasing screw speed from (1.50, 1.90 , and $2.25 \mathrm{~m} / \mathrm{s}$ ) tends to increase machine productivity from ( 0.31 , 0.37, and 0.47 ton $/ \mathrm{h}$ ), pellets durability from (92.5, 93.4, and 95.66 \%), floating time from (270, 295, and $330 \mathrm{~min}$.) and pelleting efficiency from (96.4, 97.2, and 98.4\%), respectively. And decreasing energy requirements from (9.27, 8.59 and $7.45 \mathrm{~kW} . \mathrm{h} /$ ton), and pelleting bulk density from (0.96, 0.81 and $\left.0.74 \mathrm{gm} / \mathrm{cm}^{3}\right)$, respectively. Increasing ration moisture content from $(12.8,16.5$, and $22.0 \%)$ led to increase energy requirements from ( $7.31,7.95$ and $9.27 \mathrm{~kW} . \mathrm{h} /$ tom), floating time from (240, 250, and $270 \mathrm{~min}$.) and pelleting durability from (92.50, 93.40, and 95.66 \%), respectively. And decreasing machine productivity from $(0.31,0.26$, and $0.23 \mathrm{ton} / \mathrm{h})$, pellets bulk density from $\left(0.96,0.90\right.$, and $\left.0.86 \mathrm{gm} / \mathrm{cm}^{3}\right)$ and pellets efficiency from $(98.4,97.9$, and $97.2 \%)$, respectively.

1- Senior Researcher, Agric. Eng. Res. Inst.,(AEnRI),Dokki, Egypt.

2- Agric. Eng. Dept., Fac. Agric., Assiut Branch, Al-Azhar Univ., Egypt.

3- Researcher, Agric. Eng. Res. Inst.,(AEnRI), El-Giza, Egypt. 
By increasing screw pitch from (50.0 and $80.0 \mathrm{~mm}$ ) tends to increasing machine productivity from (0.32 to 0.38 ton/h), pelleting efficiency from (95.9 to $97.2 \%)$, and pellets bulk density from $\left(0.90\right.$ to $\left.0.96 \mathrm{gm} / \mathrm{cm}^{3}\right)$, respectively. and decreasing energy requirements from (9.27 to 8.82 $k W . h / t o n)$, floating time from (240 to $210 \mathrm{~min}$.$) , and pellets$ durability from (90.15 to $88.11 \%$ ), respectively.

\section{INTRODUCTION}

T $\mathrm{n}$ Egypt in general, there is a great shortage in animal feed stuff, which is one of the most serious problems facing the animal producer. The fish is among the most important sources of proteins. Fish production from the natural sources is 350 thousand ton yearly, which is not enough to satisfy local consumption. In Egypt the share of consumed fish is $16 \mathrm{~kg} / \mathrm{man} /$ year.

Extrusion processing is considered one of the new processing of high technology in food and feed industry. Floating and sinking extruded fish feed industry is used as a new technology in a large scale all over the world to optimize the quantity of fish feed meal in agricultural farms. Both the geometrical dimension of die and ration components are the most important parameters influencing the efficiency of extrusion machine and pellets quality. Kholief (1996) showed that when the moisture content in pellets increase led to decrease in power requirement, pellet hardness and stability of pellets. He indicated that the increase of the outlet diameter increased machine productivity and mass lost of pellets but decreased the density of pellets. Soliman et al. (1999) studied the quality of wheat bran pellets related to pelleting parameters. The quality index indicates the best pelleting treatments which was prepared at $13 \%$ moisture content, pressing under compression of $56.98 \mathrm{Mp}_{\mathrm{a}}$, at temperature of $90 \mathrm{C}^{\mathrm{o}}$ and cross head speed of $20 \mathrm{~mm} / \mathrm{min}$. Afify (2001) developed the mixing unit in local pelleting machine to avoid the strangulation in the unit with the high speed. The development was constructed and tested under different conditions of mixing speed 70, 150, 215 , and $300 \mathrm{rpm}$, and concave hole diameter of 1,2 , and $3 \mathrm{~mm}$. He mentioned that the increasing the production rate, pelleting efficiency, mixing efficiency, durability and bulk density and decreasing the energy requirement, total losses, operating cost, criterion cost and total cost for 
the residues diet than the control diet with the developed mixing unit. Hegazy et al.(2002) developed of an oil expression machine to suit production of livestock feed pellets. The results revealed that the optimum values for the operations conditions were obtained at $135 \mathrm{rpm}$, screw revolving speed, $14 \mathrm{~mm}$ die hole diameter and $13.3 \%$ (d.b) raw material average M.C. At these levels maximum machine productivity of $(0.174 \mathrm{ton} / \mathrm{h})$, minimum energy consumption $(33.07 \mathrm{~kW} . \mathrm{h} / \mathrm{ton})$, mixing efficiency $(75.9 \%)$ and pellets hardness(13.2N) were obtained. Kaddour (2003) developed a local pelleting machine in the compaction pressure unit by single screw extrude to produce the cook pellets. The optimum results were recorded with the production rate of $362.77 \mathrm{~kg} / \mathrm{h}$, energy requirement of $27.071 \mathrm{~kW} . \mathrm{h} / \mathrm{ton}$, pellets bulk density of $0.91 \mathrm{gm} / \mathrm{cm}^{3}$, pelleting efficiency of $96.092 \%$, pellets durability of $97.825 \%$ and cost of $896.22 \mathrm{LE} /$ ton using screw speed of $1.81 \mathrm{~m} / \mathrm{s}$, fineness degree of $1 \mathrm{~mm}$, effective hole of $25.5 \mathrm{~mm}$ and holes number 22. El-Nono (2005) investigated the possibility of molding compost of livestock into pellets .An auger machine prototype was used for pelleting cheep manure that mixed with $(0.0-15 \%)$ for rice straw by weight, at $40 \%$ M.C. Dies of 5 , 8 , and $10 \mathrm{~mm}$ hole diameter were used. He indicated that compost pellets is suitable for recycling, storing and handling. The pellets $5 \mathrm{~mm}$ in diameter are strong enough to be applied and distributed evently by the machine without disintegrating or generating dust. They could be leached off their bases and release nitrogen and other minerals after several weeks of application. Aboud et al. (2005) used whey as a binder materials in pelleting process. The results showed that the whey was a good binder and the pellets properties were improved. The optimum why percent as binder gives durable pellets and high productivity in the rang of (10 to 15\%) as solid content. Kaddour et al. (2005) studied the effect of using stem-lock on the efficiency of extruder pelleting machine to produce the floating fish feed mill pellets. The optimum results were recorded with (392.96 kg/h production rate),(93.74\%pelletingefficiency), $\left(0.6842 \mathrm{~g} / \mathrm{cm}^{3}\right.$ bulk density), (447min.floating time) and (147.73 kW.h/ton energy requirements) using the optimum operation condition of the machine such as (type of screw of 4 single screw+1unit twin screw),(number of stemlock of 3 units),(clearance between steam-lock and internal case of $1.5 \mathrm{~mm}$ ), and (width of flat sector in steam-lock of $0.048 \mathrm{~cm}$ ). Kaddour et al.(2006) evaluated the two previously kinds of ration and taken into 
account the effective design parameters. The obtained results were summarized as follows. The optimum conditions for producing a good quality of pellets from standard ration were $1.92 \mathrm{~L} / \mathrm{D}$ ration, $18 \mathrm{~mm}$ hole entry diameter, $5.33 \%$ die opening area and $30 \mathrm{~mm}$ thickness of die, when the evaluated parameters(machine productivity, energy requirements, total losses, pellets durability, pellets bulk density, and pellets hardness) were $0.399 \mathrm{ton} / \mathrm{h}, 114.04 \mathrm{~kW} . \mathrm{h} / \mathrm{ton}, 5.21 \%, 86.72 \%, 1.190 \mathrm{~g} / \mathrm{cm}^{3}$, and 184.8N, respectively. Morad et al.(2007) studied the effect of some engineering parameters on the performance of fish pelleting machine to produce high quality fish pellets. The obtained results revealed that pelleting machine has a high efficiency $73.15 \%$, high productivity $422 \mathrm{~kg} / \mathrm{h}$ and minimum production cost $1150 \mathrm{LE} / \mathrm{Mg}$ at conditions of screw speed of $2.11 \mathrm{~m} / \mathrm{s}$ and feed rate of $432 \mathrm{~kg} / \mathrm{h}$. In order to minimize pelleting energy $50.03 \mathrm{~kW} . \mathrm{h} / \mathrm{Mg}$ and high quality fish pellets, effective hole thickness of $15 \mathrm{~mm}$ and 31 die holes were used.

The objectives of the present study are:-

1- Development of an oil small expression machine to production of fish feed pellets.

2- To study the effect of energy requirement, machine productivity, pellets bulk density, pellets durability, floating time and pelleting efficiency on performance of developed machine.

\section{MATERIAL and METHODS}

The experimental ration prepared by a hammer mill and mixed in forage mixer for mixture. The composition of the experimental ration is shown in Table 1.

Table 1: Composition of experimental ration.

\begin{tabular}{|l|c|}
\hline Composition & Percentage \\
\hline Corn ( yellow grain ) & 45 \\
Soy- bean meal & 24.5 \\
Wheat bran & 10 \\
Fish meal & 15 \\
Fish oil & 5 \\
Premix & 0.30 \\
Dl. Methionine & 0.20 \\
\hline
\end{tabular}




\section{Taken from Sakha Aquaculture Research Section.}

The experiments were carried out at Sakha Aqua cultural Research Section, Kafr El-Sheikh Governorate during season of 2007. The technical specifications and operating parameters of the developed machine to production of fish feed pellets is shown in Fig. 1and Table 2.

To fulfill the objective of this study an production fish feed pelleting machine which was tested and hoped to participate in solving the serious problems of feed shortage of fish feed pellets in Egypt.

Was used machine oil extraction locally manufactured without modification of the production and squeeze the components of pellets in order to obtain a paper pellets form using a internal cone.

Was replaced with a hay-maker internal cone feed maker is a perforated cylinder with holes $3 \mathrm{~mm}$ diameter circular distributed to the area around the cylinder. The amendment was also the end of cape screw bottoming kind of cone of the external cylindrical commensurate with the pellets cylindrical as shown in Fig. 2.

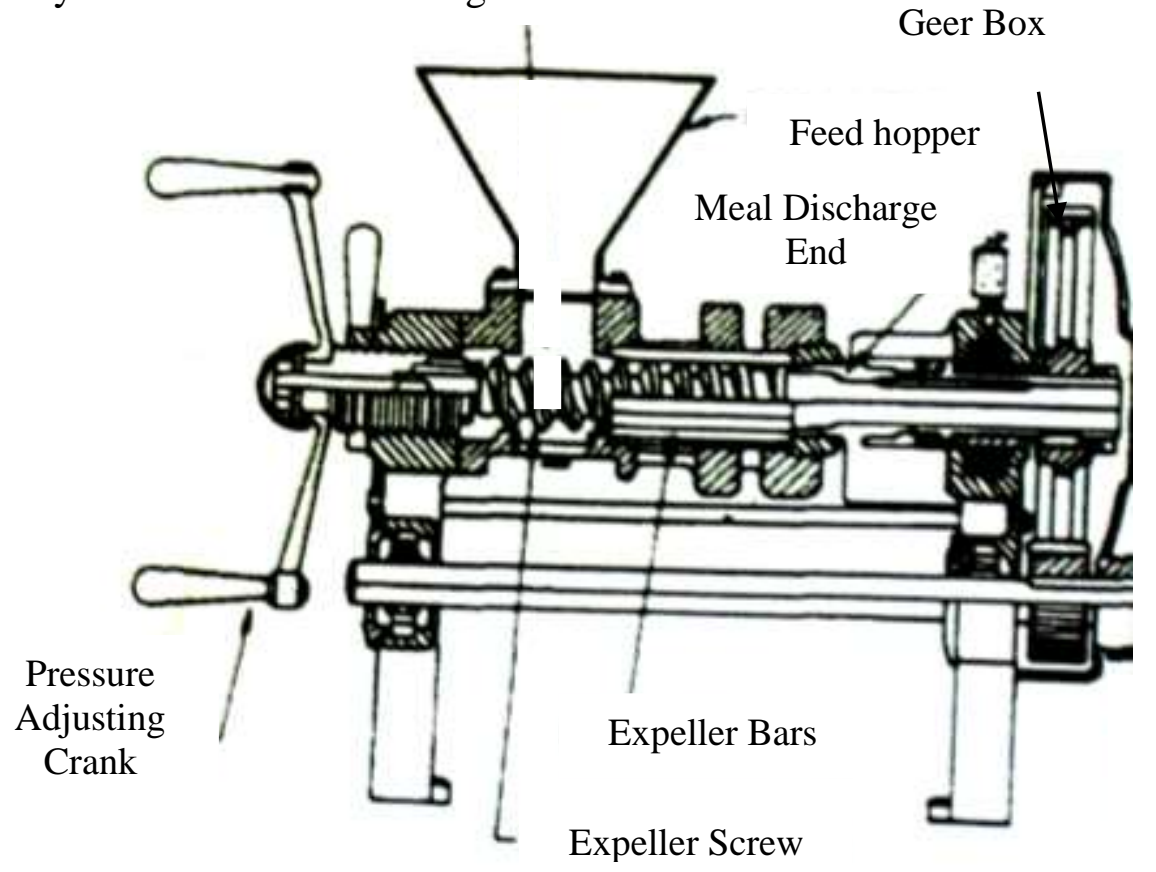

Fig. 1: Skematic digram for developed machine to production of fish feed. Also, have been using the pulley of alimonies different diameters for give different linear velocities of screw compression 

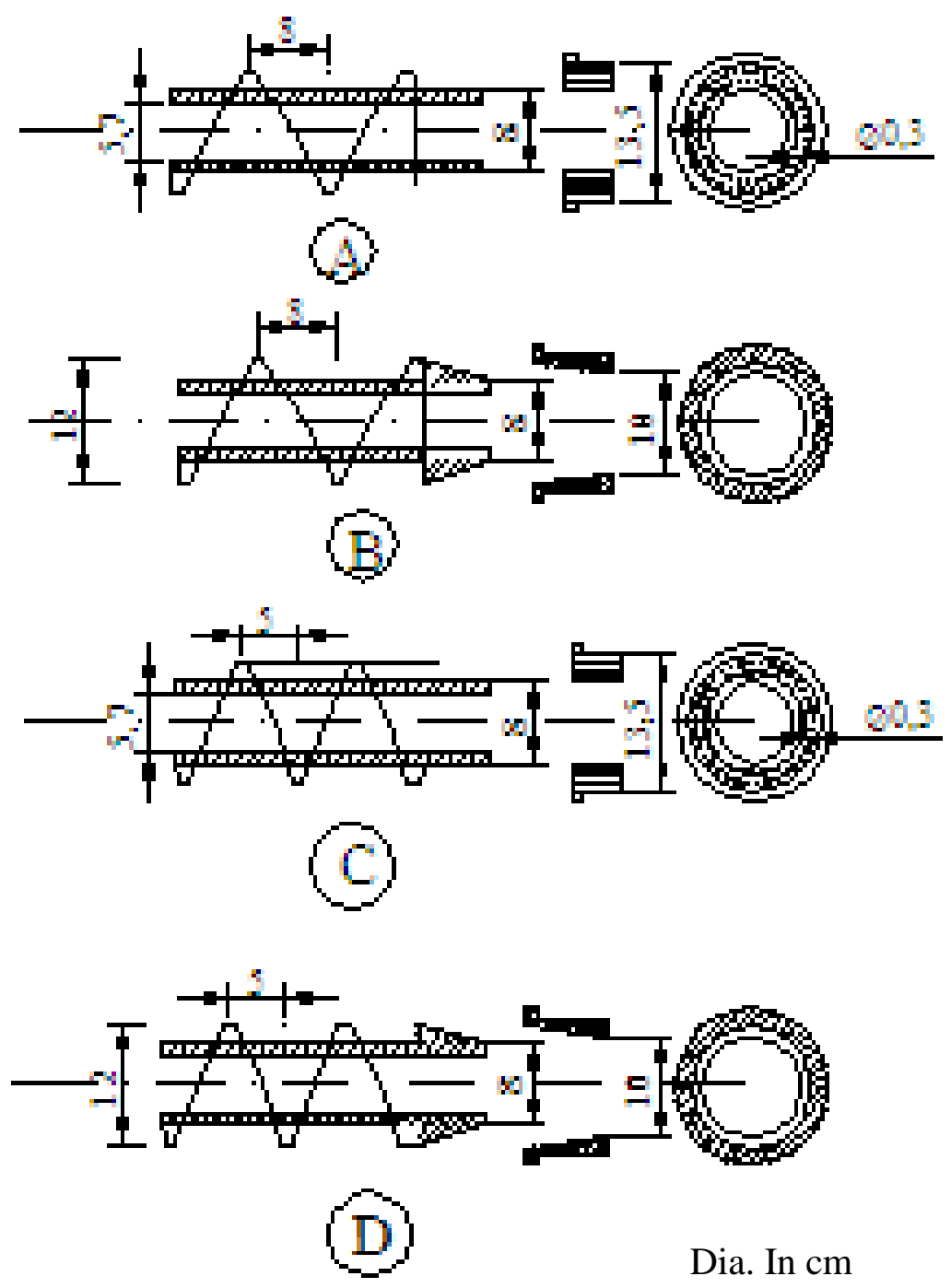

Fig. (2) : Type of die shapes:

$A$ and $C$ internal cone at 8.0 and 5.0 screw pitches

$\mathrm{B}$ and $\mathrm{D}$ perforated cylinder at 8.0 and 5.0 screw pitches

$\mathrm{A}$ and $\mathrm{C}$ machine after modification

$\mathrm{B}$ and $\mathrm{D}$ machine before modification 
Table 2: The technical specifications of the developed machine to production of fish feed pellets.

\begin{tabular}{|l|l|}
\hline Item & Specifications \\
\hline Main dimension: & \\
Overall length, cm. & 196 \\
Overall width, cm. & 65 \\
Overall height, cm. & 155 \\
Total mass, kg. & 620 \\
Screw: & \\
Length, cm. & 62 \\
Diameter, cm. & 12.5 \\
Pitch ( tough width), cm. & $5-8$ \\
Peak height ( trough depth), cm. & 1.5 \\
Hopper: & \\
Average diameter, cm. & Power source: \\
Power req. HP ( kW). & Three phase electric motor \\
\hline
\end{tabular}

The present study was conducted and taking the following factors into consideration:

1- Screw speeds $(1.50,1.90$, and $2.25 \mathrm{~m} / \mathrm{s})$,

2- Moisture content of ration $(12.8,16.6$, and $22.0 \%)$,

3- Screw pitch (50.0 and $80.0 \mathrm{~mm})$, and

4- Two different die shapes (Perforated Cylinder - Internal Cone). 1-Estimation of power consumption:-

Ammeter and Voltmeter were used for measuring current strength and potential different, respectively before and during experiments. Reading of Ammeter(I) and Voltmeter(V) were taken before and during each treatment. The power consumption $(\mathrm{P})$ was calculated using the following formula(Lockwood and Dunstan,1971):

$$
P=\sqrt{3} \cdot I \cdot V \cdot \eta \cdot \cos \theta / 1000, k W
$$

Where:

I = Current strength Amperes;

$\mathrm{V}$ = Potential difference (Voltage), Volts;

Cos $=$ Power factor, decimal (being equal 0.71 ) and

$\eta=$ Mechanical efficiency of motor assumed $95 \%$. 


\section{2- Energy requirement to produce a mass unit of pellets yield:}

Energy requirment $=$ Power,$(\mathrm{kw}) /$ Production rate, $($ ton $/ h), k W . h /$ ton $\cdots \cdots . . . .2$

3- Production rate: It was calculated from the following relation:-

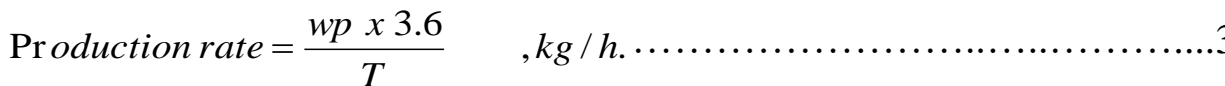

Where:

$$
\mathrm{WP}=\text { Pellets mass }(\mathrm{g}) \quad \mathrm{T}=\text { Consumed time }(\mathrm{s})
$$

4- Pelleting efficiency: It was calculated from the following relation:-

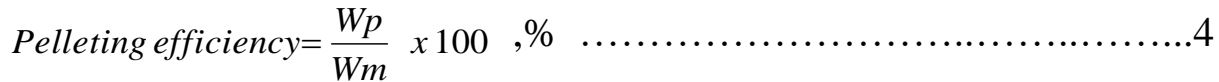

Where:

$$
\mathrm{Wm}=\text { Ration sample mass }(\mathrm{g})
$$

5- Pellets bulk density: It was calculated from the following relation:Where:

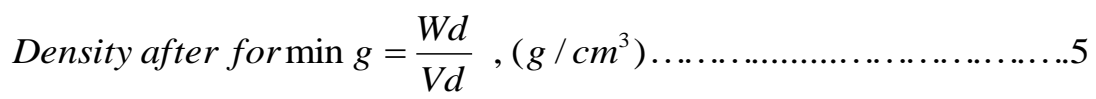

$$
\mathrm{Wd}=\text { Pellets sample mass }(\mathrm{g}) \quad \mathrm{Vd}=\text { Pellets sample volum }\left(\mathrm{cm}^{3}\right)
$$

6- Durability of pellets: It was calculated from the following relation:

$$
\text { Durability }=\frac{W a}{W b} \times 100,(\%)
$$

Where:

$\mathrm{Wa}=$ Pellets mass after shaker treatment $(\mathrm{g})$

$\mathrm{Wa}=$ Pellets mass before shaker treatment $(\mathrm{g})$

\section{RESULTS and DISCUSSIONS}

The developed machine was used to produce fish feed pellets. The experimental study in pelleting process confined to evaluate the effect of screw speed, moisture content of ration, two type screw pitchs with two type of die shapes on the following factors: ( energy requirements, machine productivity, pellets bulk density, pellets durability, floating time and pelleting efficiency).

\section{1- Energy requirement, (kW.h/ton):}

The results indicated that the moisture content of ration increase from 12.8 to $22.0 \%$ led to increase energy requirements from 7.31 to $9.27,7.00$ to 8.59 and 6.30 to $7.45 \mathrm{~kW} . \mathrm{h} /$ ton, as shown in Fig. 3 at screw speed of $1.50,1.90$ and $2.25 \mathrm{~m} / \mathrm{s}$, die shape(Perforated Cylinder), and screw pitch of $50 \mathrm{~mm}$, respectively. This is due to the increasing of moisture content of ration tends to reduce the machine productivity. 
Also, it can be noticed that screw speed increase from 1.50 to $2.25 \mathrm{~m} / \mathrm{s}$ tends to decrease energy requirements from 6.95 to $5.92,7.50$ to 6.51 and

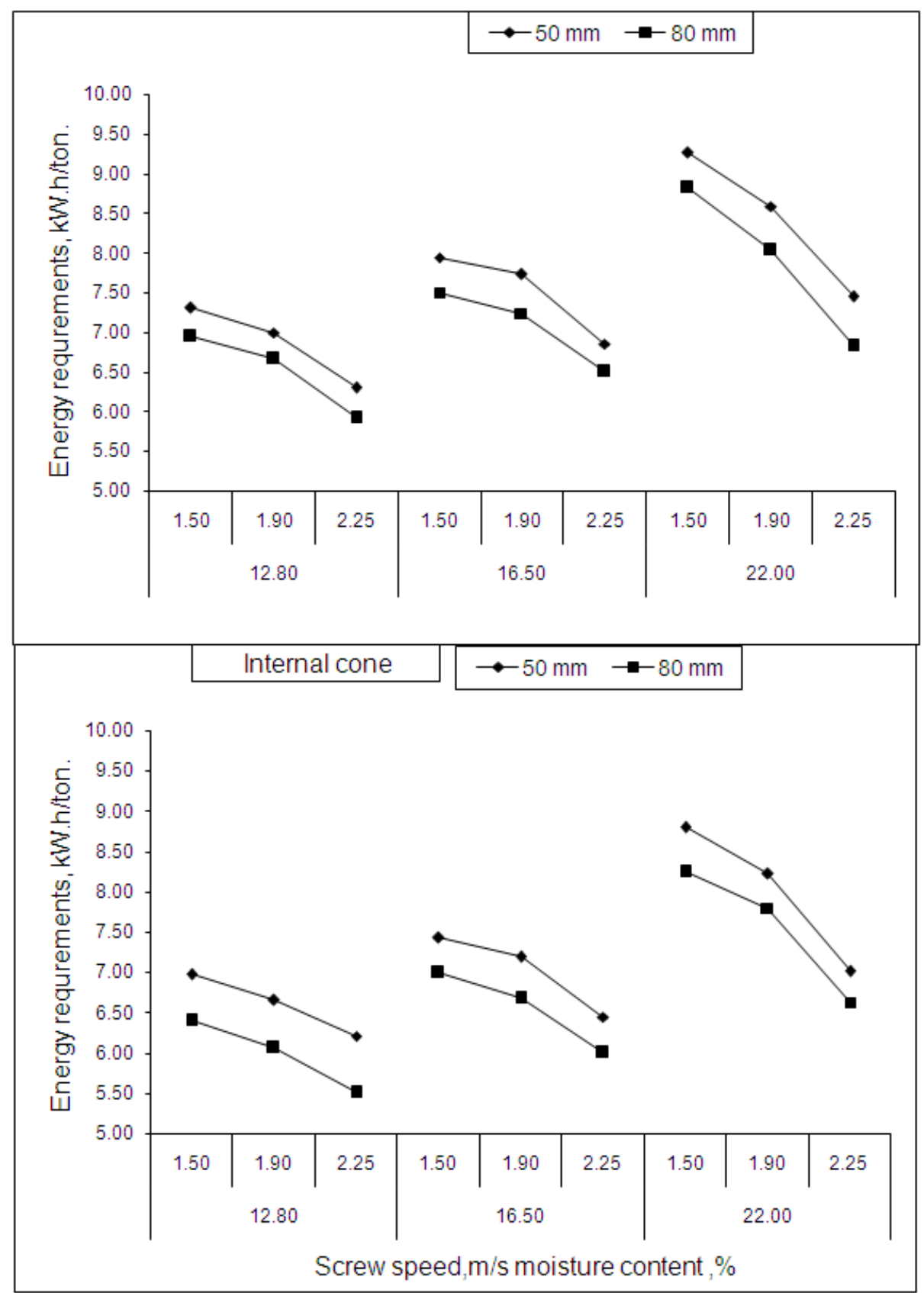

Fig ( 3 ) : Effect of screw speed, moisture content of ration and two screw pitches with two type of die shapes (perforated cylinder and internal cone) on energy requirements, $\mathrm{kW} . \mathrm{h} / \mathrm{ton}$. 
8.82 to $6.82 \mathrm{~kW} . \mathrm{h} / \mathrm{ton}$, at moisture content of ration $12.8,16.5$ and $22.0 \%$, die shape(Perforated Cylinder), and screw pitch of $80 \mathrm{~mm}$, respectively.

\section{2- Machine productivity, (ton/h):}

Machine productivity was measured during the experimental work.

Inspection of Fig. 4 illustrated that the increasing of screw speed from 1.50 to $2.25 \mathrm{~m} / \mathrm{s}$ tends to increase the machine productivity from 0.31 to $0.47,0.26$ to 0.38 and 0.23 to 0.32 ton $/ \mathrm{h}$, at moisture content of ration $12.8,16.5$ and $22.0 \%$, die shape (Internal Cone), and screw pitch $80 \mathrm{~mm}$, respectively.

In the same manner, the increase moisture content of ration from 12.8 to $22.0 \%$ led to decrease the machine productivity from 0.25 to $0.18,0.30$ to 0.20 and 0.37 to $0.24 \mathrm{ton} / \mathrm{h}$, at screw speed of $1.50,1.90$, and $2.25 \mathrm{~m} / \mathrm{s}$, die shape(Perforated Cylinder) and screw pitch $80 \mathrm{~mm}$, respectively, due to increase evaporation moisture in ration during compression

operation in high moisture content.

Also, the machine productivity in die shape (Internal Cone) more than in die shape (Perforated Cylinder) at the same screw speed, screw pitch and moisture content due to increase of outlet in die hole shape.

\section{3- Pellets bulk density, $\left(\mathrm{gm} / \mathrm{cm}^{3}\right)$ :}

Samples of pellets were taken from each treatment to measure their mass and volume to determine the bulk density of pellets.

Fig. 5 concluded that the density of pellets decreased from 0.90 to 0.65 , 0.85 to 0.62 and 0.79 to $0.60 \mathrm{gm} / \mathrm{cm}^{3}$ by increasing screw speed from 1.50 to $2.25 \mathrm{~m} / \mathrm{s}$, at ration moisture content of $12.8,16.5$ and $22.0 \%$, die shape (Internal Cone) and screw pitch $50 \mathrm{~mm}$, respectively. The decrease in pellets bulk density by increasing the screw speed may be due to the fact that high speed can not help the diet to import ticking in the die hole and the decrease in pelleting consumed time.

The increment of ration moisture content from 12.8 to $22.0 \%$ tends to decrease pellets bulk density from 0.85 to $0.71,0.75$ to 0.64 and 0.60 to $0.45 \mathrm{gm} / \mathrm{cm}^{3}$, at screw speed of $1.50,1.90$ and $2.25 \mathrm{~m} / \mathrm{s}$, die shape(Perforated Cylinder) and screw pitch $80 \mathrm{~mm}$, respectively.

By increasing screw pitch led to increase pellets bulk density, could be due to decrease in the pressure inside pelleting unit. 


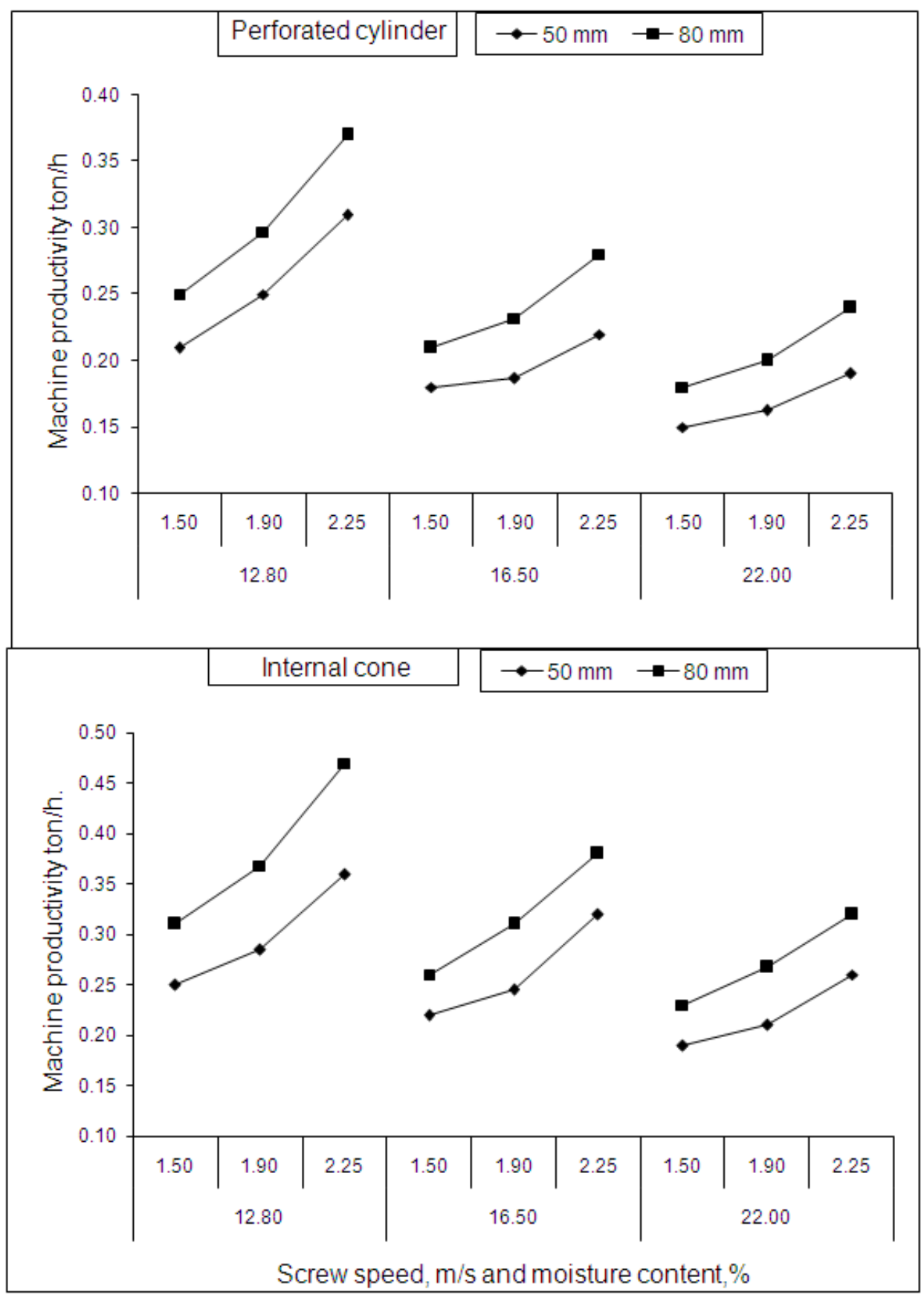

Fig ( 4 ) : Effect of screw speed, moisture content of ration and two screw pitches with two type of die shapes (Perforated cylinder and internal cone) on machine productivity, ton/h. 


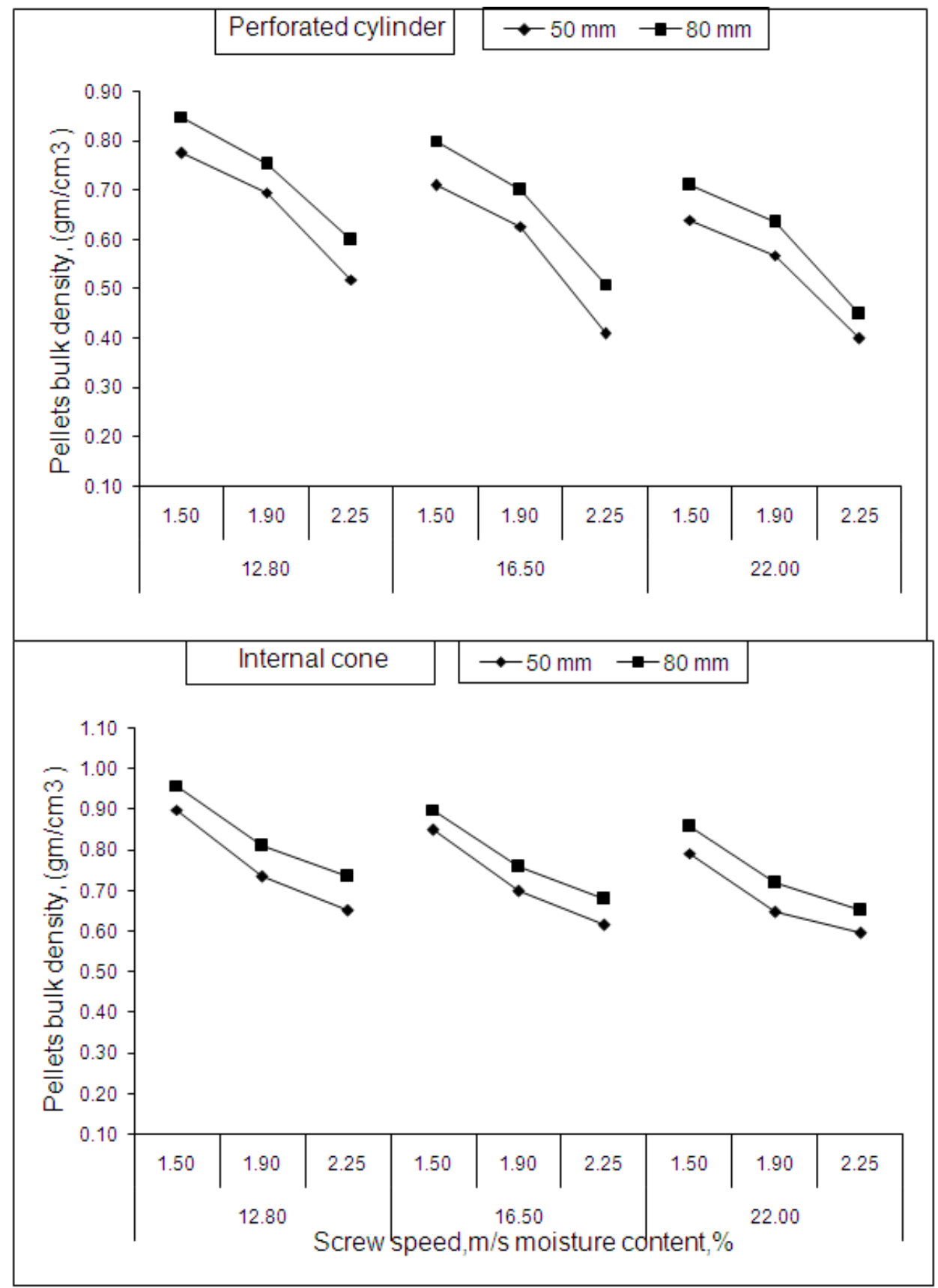

Fig ( 5 ) : Effect of screw speed, moisture content of ration and two screw pitches with two type of die shapes (Perforated cylinder and internal cone) on pellets bulk density, $\mathrm{gm} / \mathrm{cm}^{3}$. 
By increasing pellets bulk density from 0.65 to $0.74 \mathrm{gm} / \mathrm{cm}^{3}$ led to decrease floating time from 240 to $210 \mathrm{~min}$. That is due to reduction in bulk density and consequently increasing the compaction pressure to pellets and on collapsed with water reactions as shown in Fig. 6.

\section{4- Pellets durability, (\%):}

The most critical factor in the performance of pelleting machine is pellets durability.

Fig.7 indicated that by increasing the screw speed from 1.50 to $2.25 \mathrm{~m} / \mathrm{s}$ tends to increase pellets durability from 87.01 to $90.01,88.50$ to 91.80 and 89.40 to $92.92 \%$ at ration moisture content of $12.8,16.5$ and $22.0 \%$, die shape (Perforated Cylinder) and screw pitch $50 \mathrm{~mm}$, respectively.

However, by increasing the ration moisture content from 12.8 to $22.0 \%$ led to increase the pellets durability from 87.01 to $89.40,87.90$ to 90.60 and 90.01 to $92.92 \%$ at screw speed of $1.50,1.90$ and $2.25 \mathrm{~m} / \mathrm{s}$, die shape(Perforated Cylinder) and screw pitch $50 \mathrm{~mm}$, respectively.

The decrease in pellets durability by increasing the ration moisture content due to the hardness and drying pellets out put cause the high temperature inside the pelleting unit.

Also, by increasing screw pitch from 50 to $80 \mathrm{~mm}$ tends to decrease the pelleting durability due to decrease compression during compression operation.

\section{5- Pelleting efficiency, (\%):}

Pelleting efficiency is considered the most important measurements in pelleting industry. The increase of screw speed from 1.50 to $2.25 \mathrm{~m} / \mathrm{s}$ tends to increase pelleting efficiency from 95.5 to $97.0,94.7$ to 96.3 and 94.4 to $96.0 \%$ at ration moisture content of $12.8,16.5$ and $22.0 \%$, die shape(Perforated Cylinder) and screw pitch $50 \mathrm{~mm}$, respectively as shown in Fig. 8. This could be due to decrease in consumed time, pelleting losses and the increase in the production rate.

Relating to the effect of ration moisture content on pelleting efficiency in Fig. 8 it is interested to notice that the pelleting efficiency decreased from 94.8 to $93.4,95.4$ to 94.0 and 96.5 to $95.1 \%$ by increasing ration moisture content from 12.8 to $22.0 \%$ at screw speed of 1.501 .90 and 2.25 $\mathrm{m} / \mathrm{s}$, die shape(Internal Cone) and screw pitch $50 \mathrm{~mm}$, respectively. 


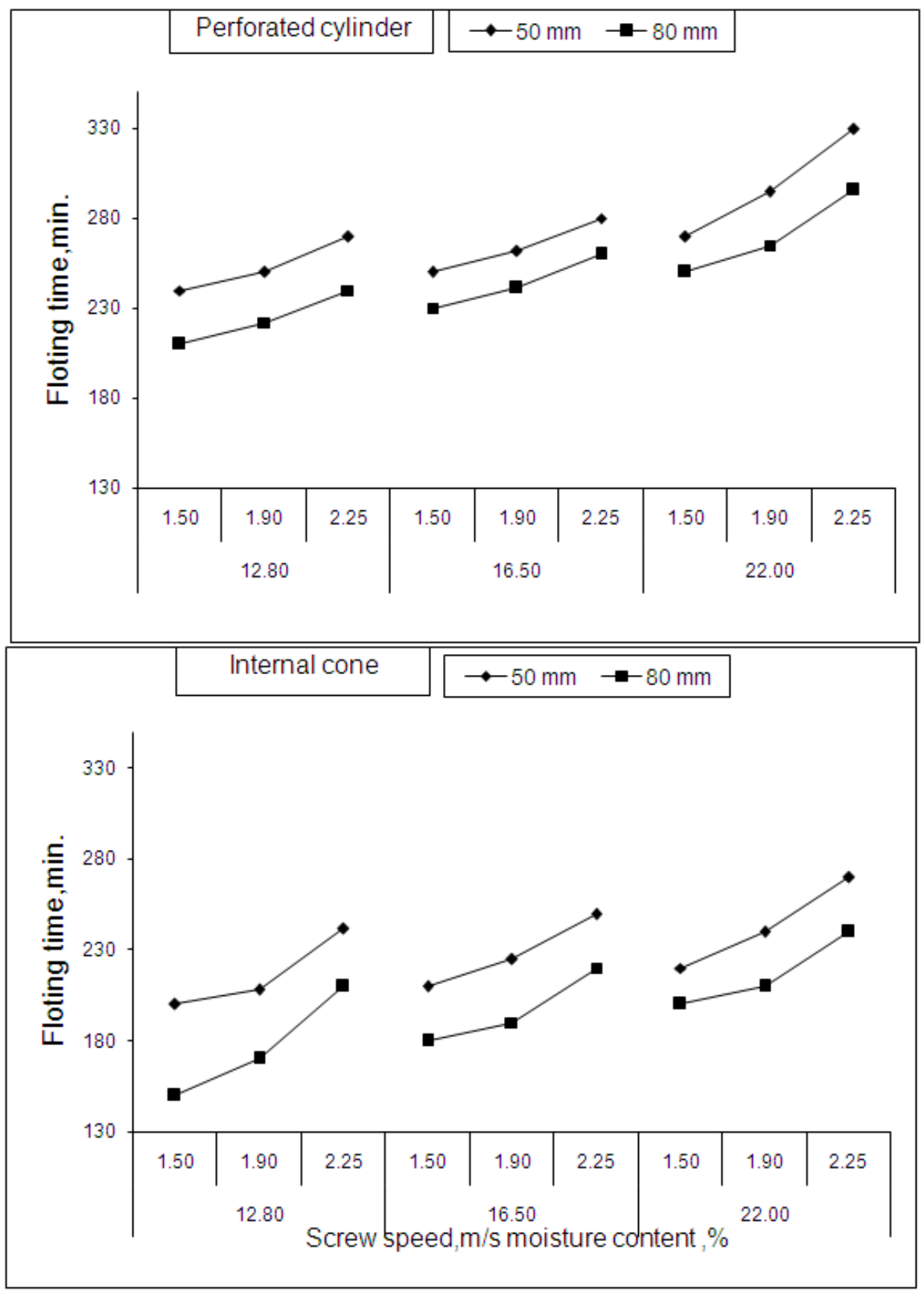

Fig ( 6 ) : Effect of screw speed, moisture content of ration and two screw pitches with two type of die shapes (Perforated cylinder and internal cone) on Floating time, min. 


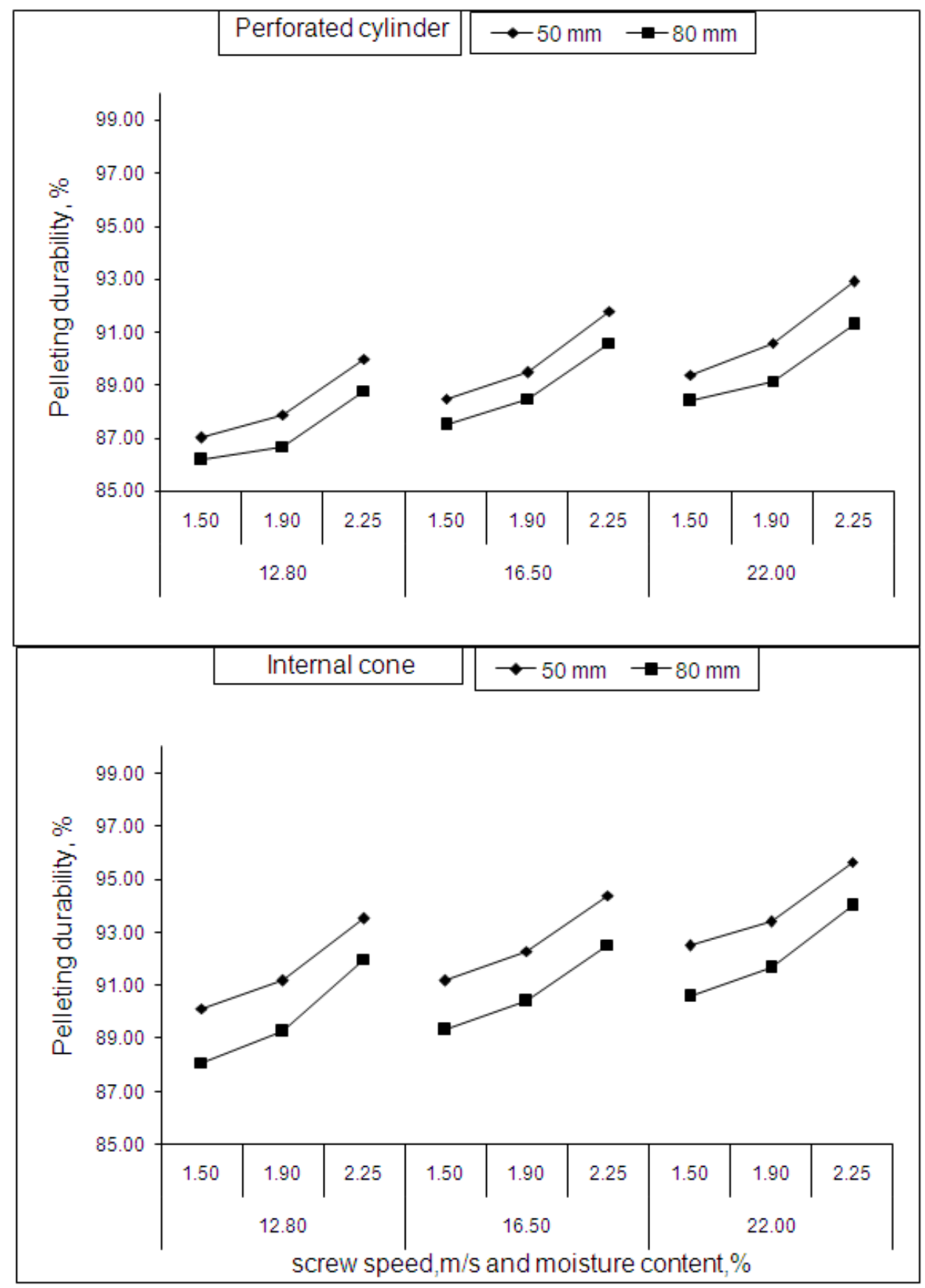

Fig ( 7 ) : Effect of screw speed, moisture content of ration and two screw pitches with two type of die shapes (Perforated cylinder and internal cone) on pelleting durability, $\%$ 


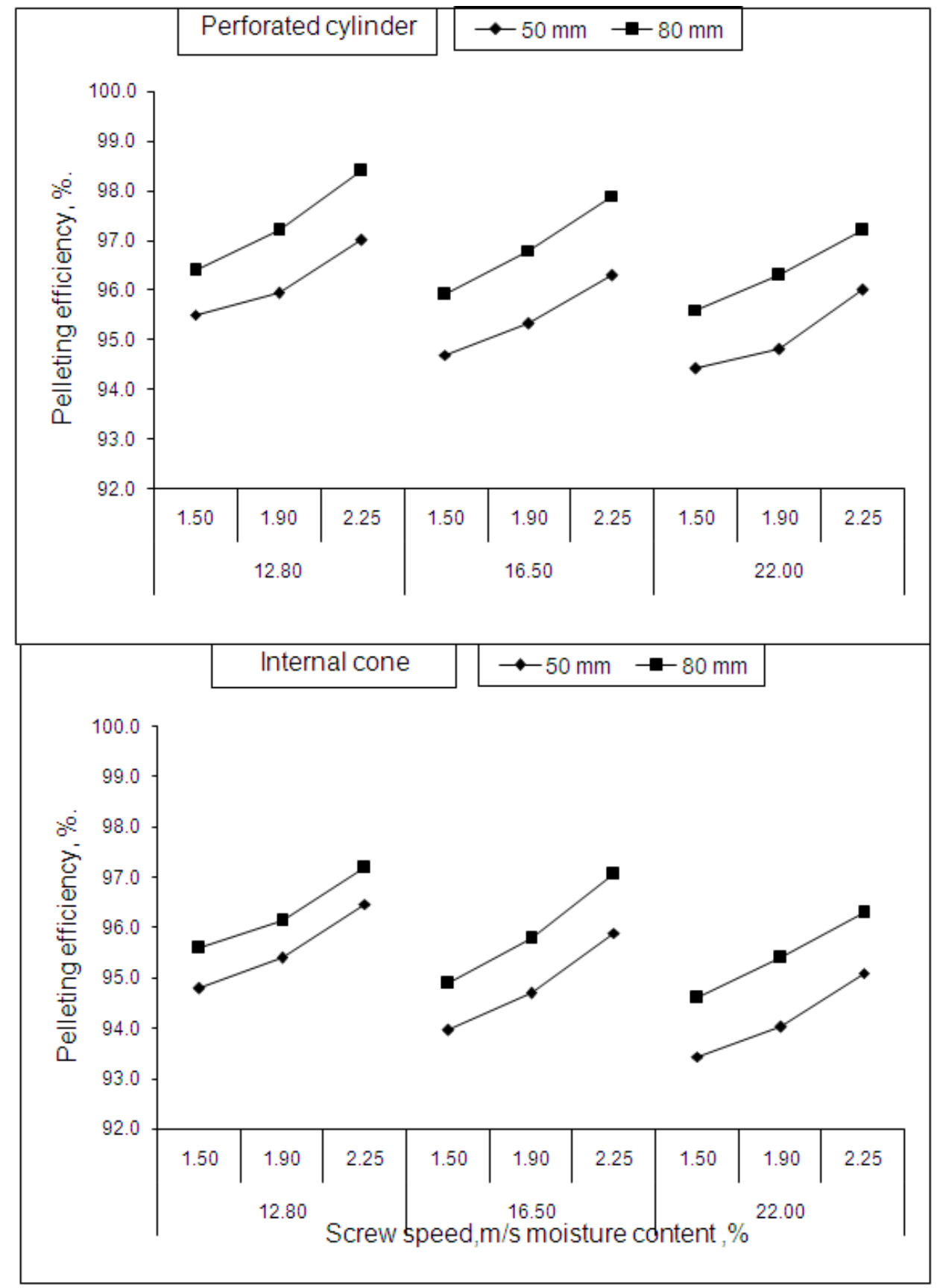

Fig ( 8 ) : Effect of screw speed, moisture content of ration and two screw pitches with two type of die shapes (Perforated cylinder and internal cone) on pelleting efficiency, $\%$. 


\section{CONCLUSION}

From this study, it can be concluded that ;

Results showed that increasing screw speed from (1.50, 1.90,and 2.25 $\mathrm{m} / \mathrm{s}$ ) tends to increase from machine productivity from $(0.31,0.37$, and $0.47 \mathrm{ton} / \mathrm{h}$ ), pellets durability from $(92.5,93.4$, and $95.66 \%)$, floating time from $(270,295$, and $330 \mathrm{~min}$.) and pelleting efficiency from (96.4, 97.2, and $98.4 \%)$, respectively. And decrease energy requirements from ( $9.27,8.59$ and $7.45 \mathrm{~kW} . \mathrm{h} / \mathrm{ton})$, and pelleting bulk density from (0.96, 0.81 and $0.74 \mathrm{gm} / \mathrm{cm}^{3}$ ), respectively.

Results showed that increasing ration moisture content from (12.8, 16.5, and $22.0 \%$ ) led to increase energy requirements from ( 7.31, 7.95 and $9.27 \mathrm{~kW} . \mathrm{h} /$ tom), floating time from $(240,250$, and $270 \mathrm{~min}$.) and pelleting durability from $(92.50,93.40$, and $95.66 \%)$, respectively. And decreasing machine productivity from $(0.31,0.26$, and 0.23 ton/h), pellets bulk density from ( $0.96,0.90$, and $0.86 \mathrm{gm} / \mathrm{cm}^{3}$ ) and pellets efficiency from $(98.4,97.9$, and $97.2 \%)$, respectively.

By increasing screw pitch from $(50.0$ and $80.0 \mathrm{~mm})$ tends to increasing machine productivity from $(0.32$ to 0.38 ton/h),pelleting efficiency from ( 95.9 to $97.2 \%$ ), and pellets bulk density from $\left(0.90\right.$ to $\left.0.96 \mathrm{gm} / \mathrm{cm}^{3}\right)$, respectively. and decreasing energy requirements from (9.27 to 8.82 $\mathrm{kW} . \mathrm{h} / \mathrm{ton}$ ), floating time from (240 to $210 \mathrm{~min}$.), and pellets durability from $(90.15$ to $88.11 \%)$, respectively.

\section{Recommendation}

The optimum conditions for operating the developed machine which gave the maximum machine productivity(ton/h), pelleting efficiency $(\%)$ and minimum energy requirement for pellets production $(\mathrm{kW} . \mathrm{h} / \mathrm{ton})$ was screw speed of $(2.25 \mathrm{~m} / \mathrm{s})$, ration moisture content of $(12.8 \%)$ and screw pitch of $(80.0 \mathrm{~mm})$.

\section{The future problems that can be studied in this field:}

To study the possibility of using automatic control system to adjust the amount of each component for raw materials and production pellets. 


\section{REFERENCES}

Aboud,A.; M.N.Awady; M.El-Ashry and M.El-Nono(2005). Using whey as a binder materials in pelleting process. Misr J.Ag.Eng.,22(4):441-453.

Afify,M.K.(2001). Development of a mixing unit in local pelleting machine. Misr J.Ag.Eng.,18(4):185-201.

El-Nono, M.A.(2005). Compost pellets made from livestock manure and rice straw. Misr J.Ag.Eng.,22(1):237-251.

Hegazy,K.S.; A.El-Ashry and M.Abd El-Rahman(2002). Development of an oil expression machine to suit production of livestock feed pellets. Misr J.Ag.Eng., 19(4): 223-236.

Kaddour,U.A.(2003).Development of local pelleting machine to produce fish feed mill cook pellets. Misr J.Ag.Eng.,20(4):538-556.

Kaddour,U.A.; T.R.Owies and H.A.El-Gendy(2005). A study on the effect of using steam-lock in extruder pelleting machine to produce floating fish feed pellets. Misr J.Ag.Eng.,22(4):266-293.

Kaddour,U.A.; T.R.Owies and M.K.Afify(2006).Influece of geometric dimensions of extrusion die holes on machine efficiency and pellets quality.J.Ag.Sci.Mansoura Univ., 32(7):337-360.

Kholief,R.M.(1996).Manufacturing of pellets production machine for livestock.Ph.D.Thesis Fac.of Agric.Kafr El-Sheikh, Tanta Univ.

Lockwood,F.B.R.Dunstan(1971).Electrical engineering principles. Meinemann Educational Books, Ltd London.

Morad,M.; M.K.Afify; U.Kaddour and V.M.Daood(2007). Study on some engineering parameters affecting the performance of fish feed pelleting machine. Misr J.Ag.Eng., 24(2): 259-282.

Soliman,N.S.; A.Z.Shoukr and M.Azhar(1999). Mechanical properties of wheat bran pellets related to pelleting factors. Misr J.Ag.Eng.,16(4):113-138.

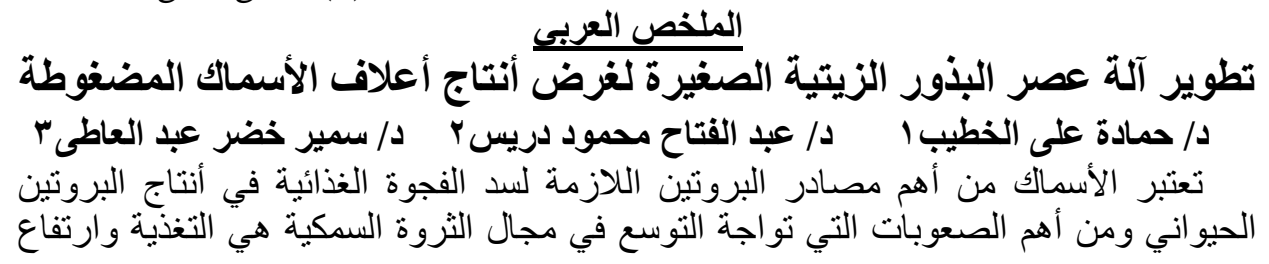

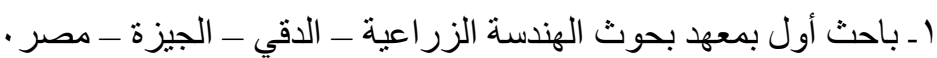

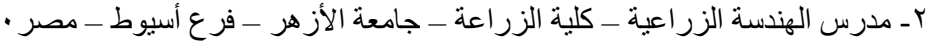

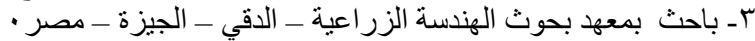


أسعار آلات تصنيع الأعلاف السمكية . حيث إن الأعلاف تشكل أكثر من ثلاثة أرباع تكلفة إنتاج

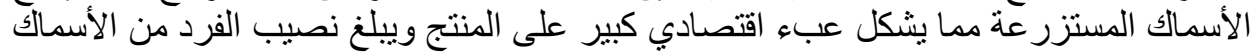

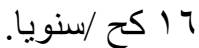
تعتبر آلات صناعة الأعلاف العاف احد المحاور الهامة التي بدا الاتجاة لها لمواجهة ارتفاع أسعار

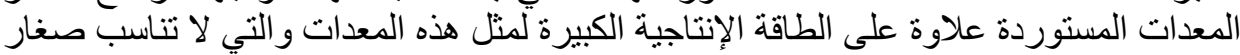

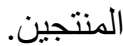

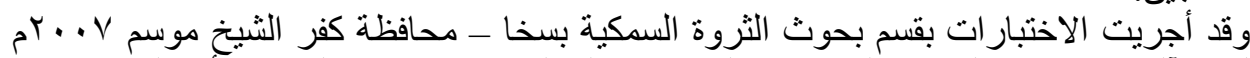

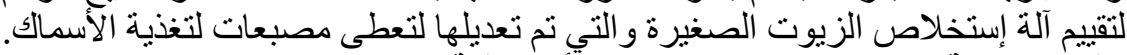

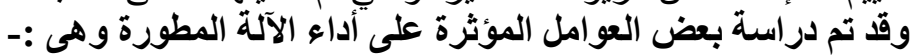

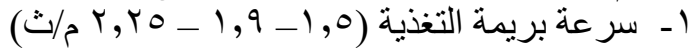

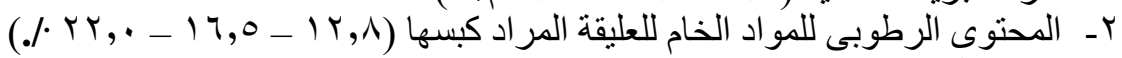

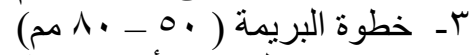

ع- - نو عان مختلفان من أقر اص مشكل العلف ( أسطو انة مثقبة - مخروط ذو سلب داخلي )

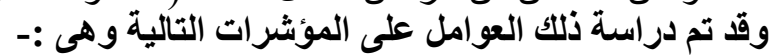

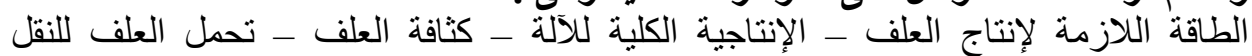

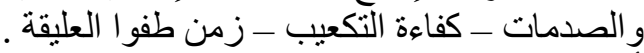

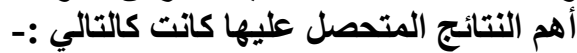

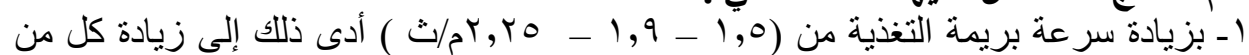

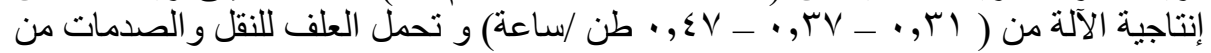

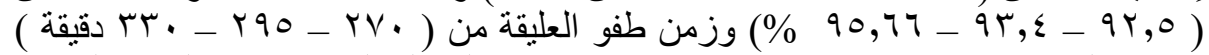

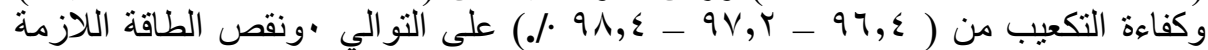
لإنتاج العلف من (V (

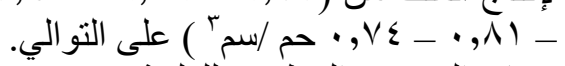

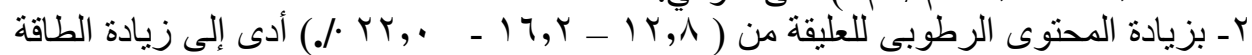

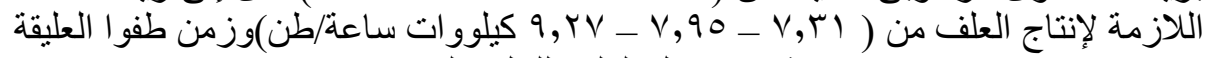

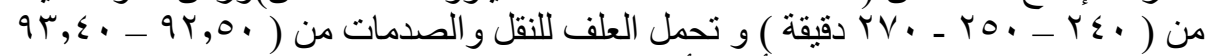

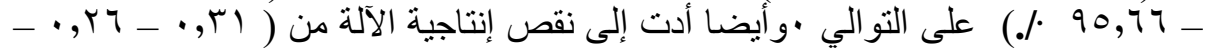

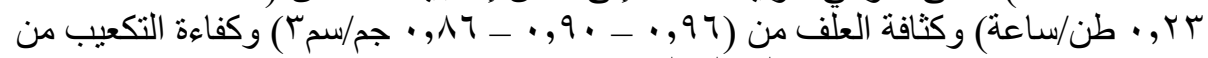

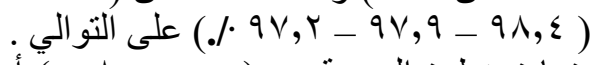

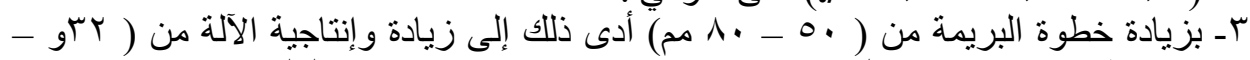

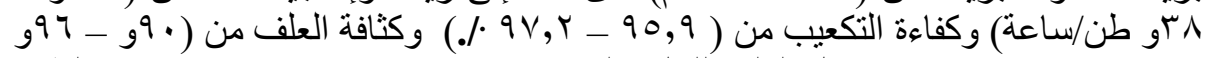

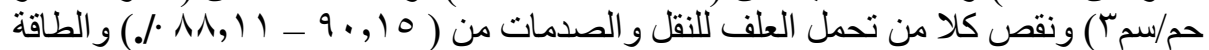

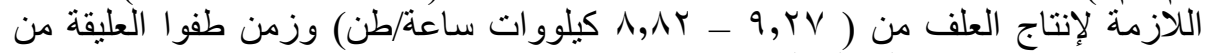

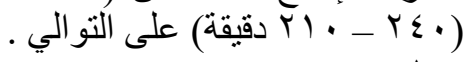

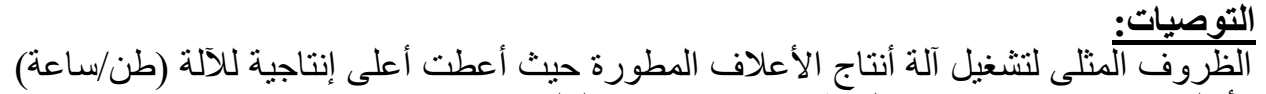

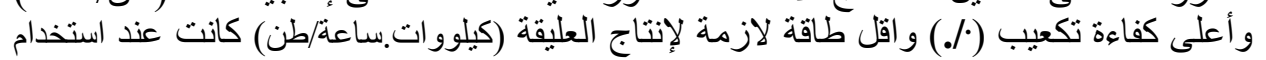

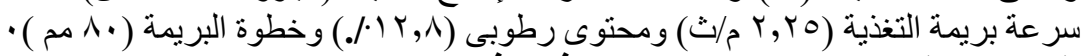

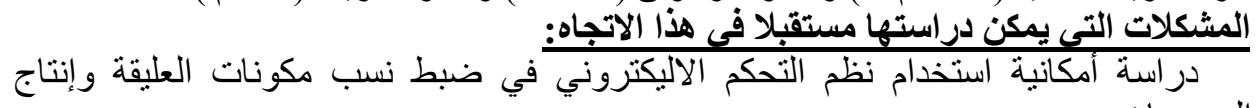
حيث أن استخدام آلات أنتاج الأعلاف سوف يشجع على زيادة المساحة المنزر عة بالأسماك خاصة في الار اضى حديثة الاستصلاح الأناع 